\title{
Novel Molten Salts Media For Production of Functional Materials
}

\author{
TKACHEVA Olga ${ }^{1, \mathrm{a}},{ }^{,}$REDKIN Alexander ${ }^{1, \mathrm{~b}}$, KATAEV Alexander $^{1, \mathrm{c}}$, \\ RUDENKO Alexey ${ }^{1,2, d}$, DEDYUKHIN Alexander ${ }^{1, \mathrm{e}}$, and ZAIKOV Yuriy ${ }^{1,2, \mathrm{f}}$ \\ ${ }^{1}$ Institute of High-temperature Electrochemistry of the Ural Branch of the Russian Academy of \\ Sciences, 20 Akademicheskaya, Ekaterinburg, Russia \\ ${ }^{2}$ Ural Federal University named after the first President of Russia B.N.Yeltsin, 19 Mira, Ekaterinburg, \\ Russia \\ a o.tkacheva@ihte.uran.ru, ${ }^{b}$ a.redkin@ihte.uran.ru, ${ }^{c}$ a.kataev@ihte.uran.ru, ${ }^{\mathrm{d}}$ a.rudenko@ihte.uran.ru, \\ ea.dedyukhin@ihte.uran.ru, ${ }^{\mathrm{f}}$ dir@ihte.uran.ru
}

\begin{abstract}
Physical-chemical properties of molten salt media based on potassium cryolite with additions of boron or scandium oxides have been considered from the point of view of their feasibility in production of functional materials, such as aluminum alloys. Liquidus temperature in the quasi-binary systems: $\quad\left[\mathrm{KF}-\mathrm{AlF}_{3}\right]-\mathrm{B}_{2} \mathrm{O}_{3}, \quad\left[\mathrm{KF}-\mathrm{AlF}_{3}\right]-\mathrm{Sc}_{2} \mathrm{O}_{3}$, $\left[\mathrm{KF}-\mathrm{NaF}-\mathrm{AlF}_{3}\right]-\mathrm{B}_{2} \mathrm{O}_{3}$, and $\left[\mathrm{KF}-\mathrm{NaF}-\mathrm{AlF}_{3}\right]-\mathrm{Sc}_{2} \mathrm{O}_{3}$ has been measured by thermal analysis. Solubility of $\mathrm{Al}_{2} \mathrm{O}_{3}, \mathrm{~B}_{2} \mathrm{O}_{3}$, and $\mathrm{Sc}_{2} \mathrm{O}_{3}$ in potassium and potassium-sodium cryolites has been determined. The potassium-cryolite-based melts were found to have an enhance protective function due to a low melting point, and an effective refining ability due to a good alumina solubility. It has been assumed that for aluminum alloys production the potassium-cryolite-based melts can be used as fluxes with improved properties as well as electrolytes for low-temperature electrolysis. Keywords: potassium cryolite, potassium-sodium cryolite mixture, liquidus temperature, solubility of oxides, fluxes.
\end{abstract}

\section{Introduction}

A modern industry is closely connected with a development of functional materials, to which the aluminum alloys belong. They can be used as constructional materials in aviation, space, nuclear industry and machine-building. In practice, the aluminum master alloys (Al-B, $\mathrm{Al}-\mathrm{Sc}$ ) are produced by the direct introduction of alloying constituent to the molten aluminum or by the aluminothermic reduction of the compound (salt or oxide) of alloying component. Production of aluminum alloys by electrolysis in cryolite-alumina electrolytes is also considered to be promising.

Molten salts media can be used as fluxes in aluminothermy or as electrolytes-solvents in electrochemical co-reduction of metals.

Flux for aluminum alloys usually presents a mixture of alkali and alkali-earth halides because it is possible to obtain compositions with variable density and liquidus temperature on their basis [1]. A NaCl- $\mathrm{KCl}$ eutectic with melting point of $665^{\circ} \mathrm{C}$ is typically used as a 
covering flux, which creates chemically passive layer protecting the aluminum alloy from oxidation. A density of molten flux has to be much less than the molten aluminum density to the effect that the layer of liquid flux could be settled on the aluminum surface. A refining effect of flux consists in adsorption and dissolution of impurities. For a better separation of molten aluminum from alumina, which always covers the aluminum surface or forms as a result of the aluminum interaction with a substance of alloying component, the flux has to be a good solvent for alumina. In general, a reaction of molten aluminum with oxides of alloying component can be written as:

$2 \mathrm{Al}(\mathrm{l})+\mathrm{M} 2 \mathrm{O} 3=2 \mathrm{M}($ in $\mathrm{Al})+\mathrm{Al} 2 \mathrm{O} 3$

where $\mathrm{M}$ is alloying component.

It is known that the alkali fluorides are capable to dissolve alumina. They act as surface-active additives, enhance wetability and conduce to separation of oxides, flux and molten aluminum. Chlorides, as well as $\mathrm{AlF}_{3}$ and $\mathrm{MgF}_{2}$, exhibit this property in much less degree. In general, fluxes can contain such fluorides as sodium cryolite $\left(\mathrm{Na}_{3} \mathrm{AlF}_{6}\right), \mathrm{CaF}_{2}$, $\mathrm{Na}_{2} \mathrm{SiF}_{6}$. However, fluorides have a high melting point that limits its application. A conventional covering flux usually contains $\mathrm{NaCl}, \mathrm{KCl}$ and $\mathrm{Na}_{3} \mathrm{AlF}_{6}$ up to $20 \%$ [1].

Potassium cryolite $\left(\mathrm{KF}-\mathrm{AlF}_{3}\right)$ and potassium-sodium cryolite mixture $\left(\mathrm{KF}-\mathrm{NaF}-\mathrm{AlF}_{3}\right)$ with low cryolite ratio (CR), which is determined as $\mathrm{CR}=\mathrm{N}_{\mathrm{KF}} / \mathrm{N}_{\mathrm{AlF} 3}(\mathrm{~mol} / \mathrm{mol})$ for the $\mathrm{KF}-\mathrm{AlF}_{3}$ or as $\mathrm{CR}=\left(\mathrm{N}_{\mathrm{KF}}+\mathrm{N}_{\mathrm{NaF}}\right) / \mathrm{N}_{\mathrm{AlF} 3}(\mathrm{~mol} / \mathrm{mol})$ for the $\mathrm{KF}-\mathrm{NaF}-\mathrm{AlF}_{3}$ mixture, are worth to be tested as basic components of flux. For instance, the $\mathrm{KF}-\mathrm{AlF}_{3}$ with $\mathrm{CR}=1.3$ has the liquidus temperature of $627{ }^{\circ} \mathrm{C}$ [2]. An undeniable advantage of the molten potassium cryolite with $\mathrm{CR}<1.7$ is a good alumina solubility within a temperature range of $700-800{ }^{\circ} \mathrm{C}$ [3]. The $\mathrm{NaF}$ addition to the $\mathrm{KF}-\mathrm{AlF}_{3}$ melt results in decreasing the alumina solubility. However, the alumina solubility in the $\mathrm{KF}-\mathrm{NaF}-\mathrm{AlF}_{3}$ mixture with $\mathrm{NaF} 10 \mathrm{wt} \%$ and $\mathrm{CR}=1.5$ still has an acceptable value of $6.7 \mathrm{wt} \%$ at $800{ }^{\circ} \mathrm{C}$. Density of molten potassium cryolite is rather low in comparison to sodium cryolite that is favorably for flux. For example, density of the NaF- $-\mathrm{AlF}_{3}, \mathrm{KF}-\mathrm{NaF}-\mathrm{AlF}_{3}$ and $\mathrm{KF}-\mathrm{AlF}_{3}$ melts with $\mathrm{CR}=1.5$ is $2.0,1.8$ and $1.7 \mathrm{~g} / \mathrm{cm}^{3}$, respectively [4]. It should be mentioned that for the last decade the fundamental and applied research in the field of low-temperature aluminum electrolysis proved an efficiency of electrolytes based on potassium cryolite, which allows carrying out electrolysis at $700-800{ }^{\circ} \mathrm{C}[5]$.

The purpose of the present study is to determine an effect of the boron-containing $\left(\mathrm{B}_{2} \mathrm{O}_{3}\right)$ and scandium-containing $\left(\mathrm{Sc}_{2} \mathrm{O}_{3}\right)$ additions to the molten $\mathrm{KF}-\mathrm{AlF}_{3}$ and $\mathrm{KF}-\mathrm{NaF}(10$ $\mathrm{wt} \%)-\mathrm{AlF}_{3}$ mixtures with $\mathrm{CR}=1.3-1.5$ on the key electrolyte properties: liquidus temperature and solubility of alumina and alloying additions, in order to identify a feasibility of the potassium-cryolite-based melts as fluxes or as electrolytes-solvents in production of aluminum alloys.

\section{Experimental}

\subsection{Salt mixture preparation.}

The individual salts (chemically pure grade) $\mathrm{AlF}_{3}, \mathrm{NaF}$, and $\mathrm{KF}$ (as $\mathrm{KF} \cdot \mathrm{HF}$ ) were used for electrolyte composition. The $\mathrm{KF}-\mathrm{AlF}_{3}$ electrolyte was obtained by mixing the $\mathrm{KF} \cdot \mathrm{HF}$ and $\mathrm{AlF}_{3}$ salts (in a glassy carbon container) and following heating to $700{ }^{\circ} \mathrm{C}$. The mixture was exposed of this temperature over four hours in order to remove HF from the melt due to the thermal decomposition of the $\mathrm{KF} \cdot \mathrm{HF}\left(\mathrm{T}=238.7^{\circ} \mathrm{C}\right)$. The $\mathrm{KF}-\mathrm{NaF}-\mathrm{AlF}_{3}$ cryolite system was prepared by mixing the $\mathrm{NaF}-\mathrm{AlF}_{3}$ and $\mathrm{KF}-\mathrm{AlF}_{3}$ binaries. Before testing the alumina $\left(\mathrm{Al}_{2} \mathrm{O}_{3}\right)$ was dried at $400{ }^{\circ} \mathrm{C}$ over 4-6 hours. 


\subsection{Liquidus temperature measurement.}

A thermal analysis (TA) was used for measuring liquidus temperature of the cryolite-based systems. This method consists in registration of thermal effects during cooling. A scheme of the installation for measuring liquidus temperature is shown in Fig.1.

\subsection{Alumina solubility determination.}

The $\mathrm{Al}_{2} \mathrm{O}_{3}$ solubility was determined according to the phase diagrams "molten cryolite mixture $-\mathrm{Al}_{2} \mathrm{O}_{3}$ ". As a rule, the phase diagrams of such quasi-binary systems have a type of a simple diagram with one eutectic. The left descending line of liquidus corresponds to the temperature of primary crystallization of the molten cryolite. It was measured using the TA. The right ascending curve of the liquids is determined by the $\mathrm{Al}_{2} \mathrm{O}_{3}$ crystallization temperature and corresponds to its solubility in molten salt at a definite temperature. In some tests the $\mathrm{Al}_{2} \mathrm{O}_{3}$ crystallization temperature was found using an isothermic saturation technique, which lies in the fact that the $\mathrm{Al}_{2} \mathrm{O}_{3}$ weight portions are to be added to the molten salt, suspended at constant temperature, until $\mathrm{Al}_{2} \mathrm{O}_{3}$ dissolves in it and the melt remains homogeneous. The saturation point for $\mathrm{Al}_{2} \mathrm{O}_{3}$ is determined using as chemical analysis as visual observation.

\section{System "potassium-cryolite-based melt - B2O3"}

In aluminothermy the $\mathrm{KBF}_{4}$ is used usually as an alloying component [6]. The main losses of this expensive substance can be a thermal decomposition with formation of a volatile $\mathrm{BF}_{3}$. In worldwide scientific practice nowadays a trial of $\mathrm{B}_{2} \mathrm{O}_{3}$, cheaper and more saturated with boron compound, have been carried out [7]. The boron oxide during interaction with molten aluminum forms alumina, which should be eliminated from the molten aluminum due to dissolution in molten salt.

The $\mathrm{B}_{2} \mathrm{O}_{3}$ influence on the liquidus temperature of the $\mathrm{KF}-\mathrm{AlF}_{3}$ and $\mathrm{KF}-\mathrm{NaF}(10 \mathrm{wt} \%)-\mathrm{AlF}_{3}$ systems is shown in Fig.2. In potassium cryolite melts the liquidus temperature increases up to 40-50 degrees Centigrade with introduction of $\mathrm{B}_{2} \mathrm{O}_{3}$ up to 3 mol.\%; further $\mathrm{B}_{2} \mathrm{O}_{3}$ addition up to $10 \mathrm{~mol} . \%$ does not impact the liquidus temperature. In the molten mixture of potassium and sodium cryolites $\left[\mathrm{KF}-\mathrm{NaF}(10 \mathrm{wt} \%)-\mathrm{AlF}_{3}\right]-\mathrm{B}_{2} \mathrm{O}_{3}$ the liqudus temperature dependence on the $\mathrm{B}_{2} \mathrm{O}_{3}$ concentration has slightly sloping character.

Fig.1 Set up for measuring liquidus temperature: 1 - cap, tightly closed;

2 - shields; 3 - tube for adding oxides in a flow of inert gas; 4 -thermocouple (Pt/Pt-Rh);

5 - glassy-carbon crucible; 6 - molten cryolite;

7 - alumina container 


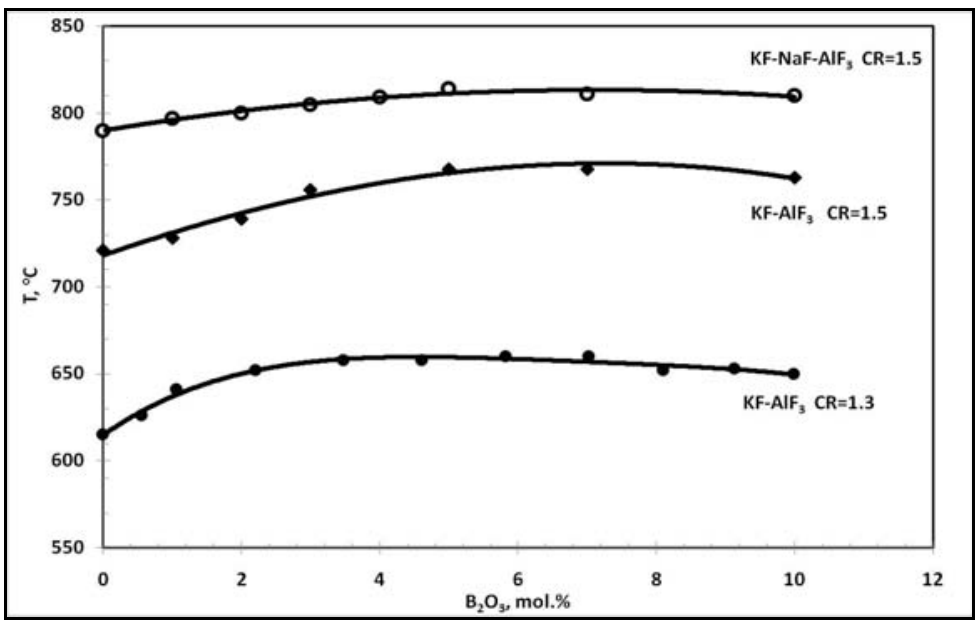

Fig.2 - Liquidus temperature of the KF-NaF(10 wt\%)-AlF3 (CR=1.5) and KF-AlF3 (CR=1.3 and 1.5) with $\mathrm{B} 2 \mathrm{O} 3$ additions

The effect of aluminum oxide additions on the liquidus temperature of the $\left[\mathrm{KF}-\mathrm{AlF}_{3}-\mathrm{B}_{2} \mathrm{O}_{3}(5 \mathrm{~mol} \%\right.$ ) $\left.)\right]-\mathrm{Al}_{2} \mathrm{O}_{3}$ and $\left[\mathrm{KF}-\mathrm{NaF}(10 \mathrm{wt} \%)-\mathrm{AlF}_{3}-\mathrm{B}_{2} \mathrm{O}_{3}(4 \mathrm{~mol} \%\right.$ ) $)-\mathrm{Al}_{2} \mathrm{O}_{3}$ systems is presented in Fig.3. The liquidus lines for the $\left[\mathrm{KF}-\mathrm{AlF}_{3}\right]-\mathrm{Al}_{2} \mathrm{O}_{3}$ [2] and $\left[\mathrm{KF}-\mathrm{AlF}_{3}-\mathrm{KBF}_{4}(5 \mathrm{~mol} \%\right.$ ) $]-\mathrm{Al}_{2} \mathrm{O}_{3}$ [8] with $\mathrm{CR}=1.3$ are also shown in this figure for comparison. The liquidus temperature of the boron-containing potassium cryolite decreases when the $\mathrm{Al}_{2} \mathrm{O}_{3}$ up to $3.2 \mathrm{~mol} \%$ is added. However, at further additions of the alumina the temperature sharply increases. It is seen that the $\mathrm{B}_{2} \mathrm{O}_{3}$ additions (up to $5 \mathrm{~mol} \%$ ) in $\mathrm{KF}-\mathrm{AlF}_{3}$ almost does not impact the $\mathrm{Al}_{2} \mathrm{O}_{3}$ solubility in the temperature range from the liquidus point to $750{ }^{\circ} \mathrm{C}$. At temperatures as high as $750{ }^{\circ} \mathrm{C}$ the $\mathrm{Al}_{2} \mathrm{O}_{3}$ solubility in the boron-containing salts is higher than that in the $\mathrm{KF}^{-\mathrm{AlF}_{3}}$ and, for example, at $800{ }^{\circ} \mathrm{C}$ it is about 4 mol.\%. The other behavior can be observed in the potassium cryolite with the $\mathrm{KBF}_{4}$ (Fig.3). The additions of this compound give an increase in the aluminum oxide solubility. In sodium-potassium cryolites the aluminum oxide mixtures immediately and sharply increase the liquidus temperature. The low solubility of $\mathrm{Al}_{2} \mathrm{O}_{3}$ in molten salts containing $\mathrm{B}_{2} \mathrm{O}_{3}$ is explained by the fact that oxides form the $\mathrm{nAl}_{2} \mathrm{O}_{3} \cdot \mathrm{mB}_{2} \mathrm{O}_{3}$ compounds with limited solubility in the cryolite melts.

Thus, mixed sodium-potassium cryolite melts cannot be recommended as fluxes in aluminothermy for obtaining the aluminum alloys at temperature as high as $800{ }^{\circ} \mathrm{C}$, when $\mathrm{B}_{2} \mathrm{O}_{3}$ is used as the boron-containing raw material. Nevertheless, the KF-AlF$F_{3}$ melts, in which the $\mathrm{B}_{2} \mathrm{O}_{3}$ solubility is about $4 \mathrm{~mol} . \%$ at $800{ }^{\circ} \mathrm{C}$, can be likely applied in electrolytic method. The $\mathrm{B}_{2} \mathrm{O}_{3}$ solubility reaction in the potassium cryolite can be written as

$$
\mathrm{KAlF}_{4}+\mathrm{B}_{2} \mathrm{O}_{3}=>2 \mathrm{KBF}_{4}+\mathrm{Al}_{2} \mathrm{O}_{3}
$$

Formed aluminum oxide will be subjected to electrolytic decomposition, and its slugs will not be accumulated in electrolytic bath. 


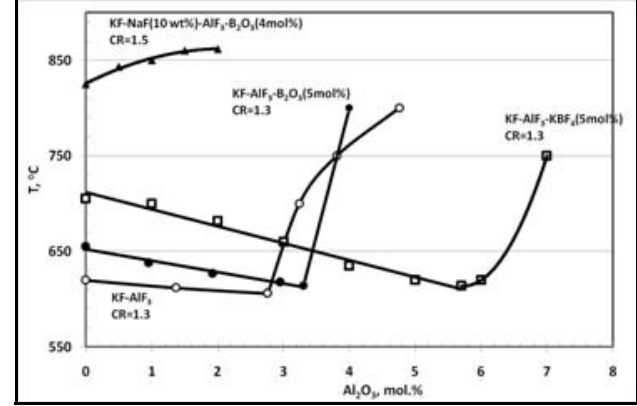

Fig.3 - Liquidus temperature of the $\mathrm{KF}-\mathrm{NaF}(10 \mathrm{wt} \%)-\mathrm{AlF}_{3}-\mathrm{B}_{2} \mathrm{O}_{3}(4 \mathrm{~mol} \%)$;

$\mathrm{KF}-\mathrm{AlF}_{3}-\mathrm{B}_{2} \mathrm{O}_{3}(5 \mathrm{~mol} \%)$;

$\mathrm{KF}_{-} \mathrm{AlF}_{3}-\mathrm{KBF}_{4}(5 \mathrm{~mol} \%)$ [8];

KF-AlF ${ }_{3}$ [2] with $\mathrm{Al}_{2} \mathrm{O}_{3}$ additions

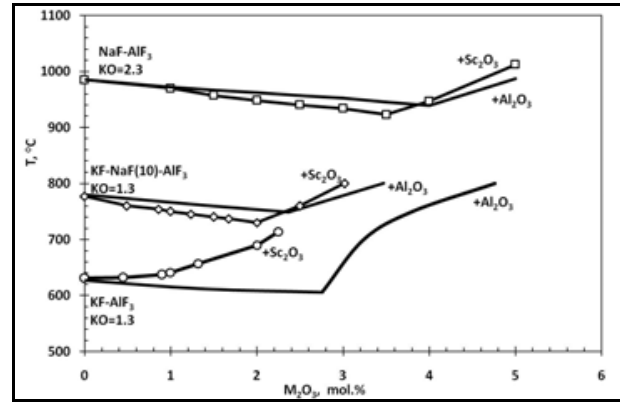

Fig.4 - Liquidus temperature in the systems: $\left[\mathrm{KF}-\mathrm{AlF}_{3}\right]-\mathrm{Sc}_{2} \mathrm{O}_{3}$ and $\left[\mathrm{KF}-\mathrm{AlF}_{3}\right]-\mathrm{Al}_{2} \mathrm{O}_{3}$ $(\mathrm{CR}=1.3) ;\left[\mathrm{KF}-\mathrm{NaF}(10 \mathrm{wt} \%)-\mathrm{AlF}_{3}\right]-\mathrm{Sc}_{2} \mathrm{O}_{3}$ and $\left[\mathrm{KF}-\mathrm{NaF}(10 \mathrm{wt} \%)-\mathrm{AlF}_{3}\right]-\mathrm{Al}_{2} \mathrm{O}_{3}(\mathrm{CR}=1.5)$; $\left[\mathrm{NaF}-\mathrm{AlF}_{3}\right]-\mathrm{Sc}_{2} \mathrm{O}_{3}$ and $\left[\mathrm{NaF}-\mathrm{AlF}_{3}\right]-\mathrm{Al}_{2} \mathrm{O}_{3}$ $(\mathrm{CR}=2.3)[9]$

\section{System "potassium-cryolite-based melt - Sc203"}

The results of the liquidus temperature measurements in the systems "potassium-cryolite-based melt - $\mathrm{Sc}_{2} \mathrm{O}_{3}$ ", promising media for performing the process of the Al-Sc alloys production are demonstrated in Fig.4. It is possible to determine the operating temperature for the process with the use of molten salts based on potassium and sodium cryolites, containing dissolved $\mathrm{Sc}_{2} \mathrm{O}_{3}$. However, choosing a molten media composition for the $\mathrm{Al}-\mathrm{Sc}$ alloys production it should be considered not only the operating temperature but a solubility of the $\mathrm{Sc}_{2} \mathrm{O}_{3}$ and $\mathrm{Al}_{2} \mathrm{O}_{3}$ in these melts.

As it is seen in Fig.4, the $\mathrm{Sc}_{2} \mathrm{O}_{3}$ solubility in molten salts containing sodium cryolite is almost the same as the $\mathrm{Al}_{2} \mathrm{O}_{3}$ solubility. An exception is the potassium cryolite $\mathrm{KF}-\mathrm{AlF}_{3}$, in which the $\mathrm{Sc}_{2} \mathrm{O}_{3}$ solubility is almost 1.5 times low than the $\mathrm{Al}_{2} \mathrm{O}_{3}$ solubility. It can be explained by formation of the slightly-soluble $\mathrm{K}_{3} \mathrm{ScF}_{6}$ compound, the melting point of which is beyond $1000{ }^{\circ} \mathrm{C}$, as a result of scandia dissolution in potassium cryolite according to the following reaction:

$$
2 \mathrm{KAlF}_{4}+\mathrm{Sc}_{2} \mathrm{O}_{3}+2 \mathrm{KF}=2 \mathrm{~K}_{3} \mathrm{ScF}_{6}+\mathrm{Al}_{2} \mathrm{O}_{3}
$$

Nevertheless, the $\mathrm{KF}-\mathrm{AlF}_{3}$ can be successfully used as flux in aluminothermy because it possesses a low liquidus temperature that positively affects its covering function, and at the same time it has a good alumina solubility that conduces removing the alumina from the reaction zone.

\section{Conclusions}

According to the experimental data obtained in the systems "potassium-cryolite-based melt $-\mathrm{B}_{2} \mathrm{O}_{3} / \mathrm{Sc}_{2} \mathrm{O}_{3}$ " it was assumed that the $\mathrm{KF}-\mathrm{AlF}_{3}$ and $\mathrm{KF}-\mathrm{NaF}\left(10 \mathrm{wt}\right.$. \%-AlF $\left.\mathrm{A}_{3}\right)$ molten mixtures with $\mathrm{CR}=1.3-1.5$ can be applied as fluxes in aluminothermy. Apart from protective function these molten salts have more effective refining ability in comparison with well-known chloride-fluoride fluxes due to good solubility of the alumina; low melting temperature, which helps to increase the flux's fluidity and strengthen its protective function. At that, it is possible to decrease a thickness of the molten flux layer over the melt, which obstructs a heat transfer because of accumulated slug (alumina) in the molten salt. 
On the other hand, the some molten compositions $\mathrm{KF}-\mathrm{AlF}_{3}$ and $\mathrm{KF}-\mathrm{NaF}-\mathrm{AlF}_{3}$ having a good solubility of the scandium or boron oxides can be recommended for electrolytic production of alloys at temperature as low as $800{ }^{\circ} \mathrm{C}$.

\section{Acknowledgements}

This work has been financially supported by the Ministry of Education and Science of Russian Federation under the Federal target program "Research and development in the priority directions of the Russia's science and technology complex progress for 2014-2020 years" based on a project "Development of energy-saving technology for producing aluminum containing boron or scandium by utilizing molten salts" (Grant Agreement N14.607.21.0042, IN RFMEFI60714X0042).

\section{References}

1. T. A. Utigard, K. Friesen, R. Roy, J. Lim, A. Silny, C. Dupuis, The properties and uses of fluxes in molten aluminum processing. JOM. 50 (1998) 38-43.

2. A. Apisarov, A. Dedyukhin, E. Nikolaeva, P. Tinghaev, O. Tkacheva, A. Redkin, Yu. Zaikov, Liquidus Temperatures of Cryolite Melts With Low Cryolite Ratio, Metallurgical and material Transaction B. 42 (2011) 236-242.

3. O. Tkacheva, Yu. Zaikov, A. Apisarov, A. Dedyukhin, A. Redkin, The aluminum oxide solubility in the KF-NaF-AlF3 melts, Proceedings of the eight Israeli-Russian bi-national workshop 2009 'The optimization of the composition, structure and properties of the metals, oxides, composites, nano- and amorphous materials', Israel, (2009) 175-182.

4. A. Dedyukhin, A. Kataev, A. Redkin, and Yu. Zaikov, Density and Molar Volume of KF-NaF-AlF3 Melts with Al2O3 and CaF2 Additions, ECS Trans. 64 (2014) 151-159.

5. O. Tkacheva, J. Hryn, J. Spangenberger, B. Davis, T. Alcorn, Operating parameters of aluminum electrolysis in KF-AlF3 based electrolytes, Light Metals (2012) 675-680.

6. Y. Birol, Production of Al-B alloy by heating Al/KBF4 powder blends, J. Alloys and Compounds. 481 (2009) 195-198.

7. Savas O. Savas, R. Kayikci, A Taguchi optimization for production of Al-B master alloys using boron oxide, J. Alloys and Compounds. 580 (2013) 232-238.

8. A. Kataev, O. Tkacheva, A. Redkin, A. Rudenko, A. Dedyukhin, and Yu. Zaikov, The Behavior of KBF4 in Potassium-Cryolite-Based Melts, Journal of The Electrochemical Society, 162 (2015) H283-H286.

9. Yu. Zaikov, O. Tkacheva, A. Suzdaltsev, A. Kataev, Yu. Shtefanyuk, V. Pingin, D. Vinogradov. Lab Scale Synthesis of Al-Sc Alloys in NaF-AlF3-Al2O3-Sc2O3 melt. Advanced Materials Research 1088 (2015) 213-216. 